\title{
The challenges of globalisation for development in southern Africa
}

\author{
Andre C Jordaan
}

The world is currently engaged in a process of globalisation, as is reflected in the growth of world trade, unification of capital markets, internationalisation of production, distribution networks and the megarevolution in information, communications and technology. Globalisation presents both opportunities and challenges for developing countries, especially the southern African region. It also demands that the region becomes competitive in attracting investment, applying new technology, and producing goods and services that can compete efficiently on the global market. The main purpose of this article is therefore to consider whether southern Africa is likely to enter a global community successfully, and be prosperous in the process.

\section{INTRODUCTION}

'The future might not be knowable but it is certainly imaginable' (Bethlehem, 1991: 4). Southern Africa is confronted with this question: What effect will the wave of globalisation have on the region's internal and external economic performance? In assessing the prospect of globalisation, it is necessary to view briefly the socio-economic profile of the region. It consists of 14 states that vary considerably in economic strength. Approximately 200 million people with an average gross national product (GNP) per capita of \$954,52 (1995) inhabit the region. The average annual inflation rate was 40,6 per cent during 1985-95 and the adult illiteracy rate was 28,27 per cent in 1995 (World Bank, 1997). Compared with international standards, this does not paint an impressive picture.

The Economist (1994: 13) has asked the question: 'Does it matter where you are?' In the real world, geography counts a great deal and it does matter where one is, especially if one happens to be at the southernmost tip of Africa. The question thus arises whether southern Africa is capable of meeting the challenges of economic globalisation, or will this be another issue that is used as an excuse to blame the world for one's own misery? The issue of globalisation can indeed be seen either as a threat or a challenge to southern Africa. The main purpose of this article is therefore to consider whether the region is likely to enter a global community successfully, and be prosperous in the process.

\section{GLOBALISATION}

\subsection{Defining globalisation}

Addressing the issue of globalisation is a bit like looking in the rear-view mirror of a motorcar in an attempt to make predictions about the road ahead. Globalisation is one of the most powerful and pervasive images in the world today. What is fascinating about globalisation is that it may be used as a reason, or an excuse, for almost anything. Nearly all private actions or public policies can be justified in some way as a response 
to the effects of globalisation, be they positive or negative, real or perceived (Veseth, 1998: 12).

The root cause of misunderstanding globalisation is that of ignoring its complexity. Complex social issues that are difficult to understand are simplified; we take some facts into account while ignoring others (or taking them as a given fact). If the issue is complex enough, it is possible to see exactly what one wants to see (Veseth, 1998: 90).

Globalisation conveys the widely accepted idea that we are living in a borderless world. According to this view, globalisation signifies the end of geography. Notice is no longer taken of distance or national policy, and national governments must accommodate what global markets dictate (Veseth, 1998: 21). On the political map the boundaries between countries may be very clear, but on the competitive map that shows the flows of financial and industrial activity, such boundaries have largely disappeared. National economies are no longer immune to external influences and cannot be insulated from global effects.

Defining the concept of globalisation is not a simple matter. According to the New Oxford Dictionary (1998: 780), globalisation is to 'develop or be developed so as to make possible international influence or operation', and a global village is one where the 'world is considered as a single community linked by telecommunications'. According to Veseth (1998: 25), globalisation is one of those fuzzy but familiar concepts that we understand when we are asked about it, but need some thought before we can explain or define it. Petrella (1996: 65) finds globalisation too vast an idea to express in a single sentence and therefore tries to capture its meaning through a list of related concepts:

- Globalisation of finance and capital ownership.

- Globalisation of markets, strategies and competition.

- Globalisation of technology, research and development, as well as knowledge.

- Globalisation of ways of life and consumption patterns (culture).

- Globalisation of regulation and governance.

- Globalisation as the political unification of the world.

- Globalisation of perception and consciousness.

Global consciousness has been defined as 'receptiveness to (and understanding) of cultures other than one's own, often as part of an appreciation of world socio-economic and ecological issues' (Robertson, 1992: 8). In general terms, globalisation imparts a notion of compression or shrinking. It is also the process of economic, political and social change that occurs when all participants in a system have access to a common pool of resources. This common pool includes markets for capital, science, technology, goods and services and cultural goods. Access to the global resource pool changes the dynamics of the system, as well as the nature of competition (Veseth, 1998: 26).

The nature of competition changes if individual firms benefit from the resources that they draw from the global pool, especially if they do not bear all the costs. Costs will be reduced if firms are able to employ labour and utilise natural resources without having to invest in a region's education, training and environmental protection. In a global market, a firm can move on if resources in a specific region have been depleted. In this sense, a temporary competitive advantage is experienced and a 'free rider' problem arises (Veseth, 1998: 26). Financial markets constitute that element of the common resource pool that comes closest to being truly global. It is therefore important 
to realise that financial markets constrain what governments can do, and not the other way around.

Currency crises are among the realities of today's international financial markets. Exchange rates are subject to a variety of forces that may cause them to fall suddenly and steeply, and this cannot always be attributed to poor or unrealistic decisions, choices and policies. The sources of currency crises, their timing, incidence and impact are not always known. This means that there is a lack of information on some very important matters prior to what may be an economic disaster for a country.

A common resource pool implies that a country has the necessary means to share in that pool. In southern Africa's case, however, owing to inadequate access to global resources, among other things, this cannot be taken for granted. Therefore it cannot be assumed that southern Africa will be able to reap the perceived benefits of globalisation in the same way as other regions. For the purpose of this article, we will therefore ascribe to the fact that no country or economy can function in total isolation, but that it does not necessarily have automatic access to global resources and may influence or be influenced by the rest of the world.

\subsection{Information}

The flow of information plays a major role in eliminating boundaries between countries. Information that was monopolised by governments was often treated as they saw fit and redistributed in forms that suited their own purpose. Such monopoly of information about what was happening in the world 'enabled them to fool, mislead or control the people, because only the governments possessed real facts in anything like real time' (Ohmae, 1991: 19). Today, people are increasingly able to acquire information from all corners of the world. Consumers want to buy the best products at the best prices, no matter where in the world these are produced. The direct flow of information to the consumers is eroding the ability of governments to pretend that their own interests are in harmony with those of their population (Ohmae, 1991: 185). According to Edoho (1997: 5), the information revolution is:

...hurrying the collapse of the old orders, accelerating the velocity of social and political change, creating informed and politically active publics and inciting conflict by publicising the differences between people and nations.

In some countries, a lack of information may still represent serious limitations to the establishment of an environment populated by well-informed citizens. Successful development therefore entails acquiring and using knowledge to close this perceived gap in knowledge between societies. Developing countries who wish to position themselves and take advantage of the existing opportunities basically have a threefold task (World Bank, 1998/9):

- The acquisition and adaptation of global knowledge.

- Investment in human capital to improve the ability to absorb and apply the knowledge.

- Investment in technology to facilitate both the acquisition and the absorption of this new-found knowledge. 


\subsection{Technology and employment}

Less-developed countries, still producing goods largely derived from their land, continue to hanker for more territory. In economies where capital, labour, technology and information are mobile and have risen to predominance, no such craving for land remains. According to Veseth (1998: 23), 'the world is embarked on a progressive emancipation from land as a determinant of production and power'. Only Third World countries seem to think that territory still matters.

Howells \& Wood (1993: 3) noted that:

Technology is a basis, stimulant and medium for collaboration among firms, for investment and trade and for organising and managing international operations. Reciprocally, globalisation is changing the ways in which knowledge is produced, converted to technology and the technology transformed into goods and services.

It may be assumed that the innovation and expansion of technology will have some as yet unknown effect on the level of employment. Some people are convinced that there will be a dramatically negative effect on the creation of employment. According to the advocates of the 20:80 society, 20 per cent of the world population will suffice to keep the world economy going in the next century. More labour power is not necessary as one-fifth of all job seekers will produce enough to meet world demand. The remaining 80 per cent will remain unemployed (Martin \& Schumann, 1997: 3). This is an alarming factor that can already be seen in a country such as Germany, where 6 million jobseekers - more than at any time since the founding of the Federal Republic - could find no secure employment in 1996. Similar trends have been reported in Austria, where 10 000 industrial jobs disappear every year (Martin \& Schumann, 1997: 5).

A study undertaken by the International Labour Office (ILO, 1999) provides empirical evidence that trade liberalisation in South Africa may have shifted production in favour of capital-intensive sectors and to the detriment of labour-intensive ones. The study also states that the chronic shortage of skilled labour had a negative consequence in terms of economic growth and may have hindered the development of labour-intensive sectors. It concludes that this hampers the ability of the labour market to adapt to the instability often associated with globalisation.

The effect that international information technology will have on employment has not yet been clarified. Blignaut (1999: 7) argues that although some observers are convinced that information technology creates as many jobs as it sheds, others feel that its positive impact on employment is exaggerated. Archibugi \& Michie (1997: 14) state the following:

Increased globalisation means that any loss of relative competitiveness translates into a far greater loss of markets - abroad and at home - with a concomitantly greater loss of jobs and threat to living standards.

This implies that in a globalised world, business will become relatively smaller but more dynamic. Opponents of this view argue that much of the current economic success the United States is experiencing is due to the availability and role of technology. Blignaut (1999: 8) agrees: 'There is talk about the possibilities of economic growth under conditions of zero inflation and zero unemployment.'

Such a situation was considered impossible after the global economic turmoil of the 
early 1970s. The development of new technologies had always played a major role in the movement towards social and economic globalisation. It is also often argued that the current process of globalisation would have been impossible without such technologies.

An important task of a government is to protect jobs, and governments may therefore follow a policy of protectionism for the sake of job security. In other words, governments would rather protect their domestic markets from foreign products and capital. Past international experience has clearly proved conventional wisdom wrong in this regard (Ohmae, 1991: 15). As markets are liberalised, wage rates normally increase in the long term. The consuming habit caves in, the economy shifts rapidly to the service sector, and the latter comes to provide more and more of the total employment. It is all about adding value and not production per se. To open up an economy, a country can take advantage of the job opportunities created in this way. This only holds if the companies invest, train, employ, pay taxes and build up infrastructure in the domestic economy (Ohmae, 1991: 195). What nations need, however, is the determination to succeed in the global marketplace. Some successful nations have learned to live with the door unlocked.

\section{SOUTHERN AFRICA}

\subsection{Introduction}

At best, the economic future of Africa (also southern Africa) appears somewhat bleak. Conclusions to the effect that 'Africa has lost control of its own destiny' (Cheru, 1997: 209) are harsh, but may well be relevant in context of the current globalisation process. Indebtedness is harmful to economic growth when scarce resources are diverted towards the payment of debt. Southern African countries are unattractive to global investors on account of their political instability, lack of accountable government, poor infrastructure and a massive brain drain. No wonder the former European Community Commissioner Claude Cheysson called them the 'useless' countries (Cheru, 1997: 213). Therefore, investor confidence must be restored and the general perception changed if southern Africa is to play a substantial role in the global economy. It is, however, important to take cognisance of the fact that almost all southern African countries are engaged in market-orientated reforms aimed at restoring investor confidence. Many previously state-owned banks have been privatised and nearly all countries have (or are in the process of) established stock exchanges. Exchange controls have also been liberalised extensively, privatisation drives have created many opportunities and various investment incentives are in place (SADC, 1998: 52).

The southern African region is viewed as the one with the greatest potential for spearheading the so-called African renaissance (Mbuende, 1998: 11). The renaissance is meant to create opportunities for people to express and develop their talents; it embraces tolerance and mutual support, and hopes to harness the collective energies of African states to achieve a common vision (Mbuende, 1998: 11). There are, however, opportunities and challenges to be overcome. The Southern African Development Community (SADC) is arguably Africa's fastest growing region but military disputes, in particular, are spoiling the potential harmony (Business Africa, 1997: 3).

\subsection{South Africa's role}

As the dominant economic force in the SADC, South Africa has the task of promoting 
the region's economic prospects. South Africa accounts for 77 per cent of the region's gross domestic product (GDP), while its per capita income is 250 per cent of the regional average and nearly 12 times that of the other 13 states (Business Africa, 1997: 3 ). Apart from the own advantage in the prosperity of its neighbours, economic instability in the region adds to the social and economic pressures in South Africa as people in the neighbouring countries seek to escape to an area of relative economic prosperity. In this regard it is important for the success of the region that South Africa becomes part of the global economy. It should, however, be kept in mind that South Africa might not necessarily have the capacity to assist its neighbours in terms of investment. It would be a great pity if domestic circumstances were to militate against the creation of a climate of good neighbourliness and economic cooperation.

The process of generating higher levels of economic growth and accelerating the development of the region should be directly linked to the foreign sector of the economy. Knowledge, information and skills from abroad is essential to increase the economic potential of the region, trade, capital and technology inflows (Scott, 1995: 199). It is in this sense that South Africa's international economic relations hold the key to both its own future and that of the southern African region.

One of the major challenges would be to become competitive by attracting foreign investment, applying new technology and producing goods and services that can compete effectively with other international role-players and penetrate industrial markets.

Factors enhancing competitiveness are the following:

- Market-based economic policies - an open economy allows international transactions in capital inflows and goods and services which improve production capacity and enhance productivity.

- Government support for a competitive economy, ie government institutions that support a modern competitive market economy, including the rule of law and protection of property rights.

- Restructuring of financial and capital markets - mobilising savings and allocating these resources efficiently to the most productive uses and investment options in the economy.

- Provision and maintenance of infrastructure - the provision and maintenance of efficient infrastructure are essential for enhancing competitiveness.

- Improving existing technology - the introduction of new technologies can transform the productivity levels, production capacities and capabilities and economic performance.

- Human capital development - this provides the required knowledge, skills and attitudes for product development, quality control, financial operations and marketing.

Competitive nations are those that have chosen correct and well-functioning institutions and policies to promote long-term growth. In this regard, the region still has a long way to go. In the Global Competitiveness Report of 1996, no southern African country was ranked among the 53 countries listed except South Africa, in position 43 (Mbuende, 1998: 13). 


\subsection{Global realities}

Scott (1995: 204) emphasises the following issues that need to be considered seriously by southern African countries in their approach to globalisation.

\subsubsection{Globalisation is a reality}

The speed at which new technology improves to reduce the limitations of space and time makes globalisation a technical possibility, while the mobility of production factors and goods and services makes it a reality. An economy will regress if it is decided to move towards an inward-orientated approach of protectionism.

\subsubsection{Market economics is globally unchallenged}

In gaining and retaining international credibility, a socialist-driven economy is simply not an option. This implies that functions such as decision-taking, information, incentives, private ownership and finance should be market-driven.

\subsubsection{International shortage of financial capital}

As the flow of financial capital is limited in relation to an unlimited world demand, potential recipients have to 'queue' and compete for much-needed foreign exchange. Depending, among others, on policies, incentives and expected returns, an economy may have to wait a long time to reach the front of the queue.

\subsubsection{Regional trading blocs}

Despite the theoretical arguments concerning the advantages of free trade, it is evident that the world is being organised into 'closed' competing trading blocs: for example, the European Union and the North American Free Trade Agreement (NAFTA). Cognisance should be taken of this fact in establishing healthy relations with others, because without strong links with some of the major trading blocs, marginalisation may become an even greater threat. It should also stimulate intraregional trade, although this depends on the potential of the trading bloc with which a country is currently involved, or of which it wants to be a part.

\subsubsection{Technology and skills versus natural resources and raw labour}

The difference between a successful and an unsuccessful economy is the existence of a motivated and well-educated labour force, access to technology and correct complementary policies. The stock of a country's natural resources is a necessary, but not sufficient, condition for economic growth. On their own, natural resources without technology will not provide the necessary tools to achieve economic prosperity. An economy with abundant land and raw labour needs to invest in human capital, import the necessary skills and technology, and use this combination to take on the global world.

\subsubsection{Military power}

The process of globalisation has changed the structure of the world economy towards the ascendance of economic power and the waning of military power. A country's 
status in this realigned global economic system does not stem from its military power, but its economic strength.

The countries of southern Africa should contemplate and consider these global realities seriously if they are to face the challenges of globalisation. An investigation of their own position with regard to these realities is extremely important in order to anticipate the probability of success.

\section{CHALLENGES OF GLOBALISATION}

The question now arises: how can South Africa become a global role-player and, in doing so, reap economic benefits for the whole region? A sound understanding of the characteristics, dynamics and significance of global developments, as well as an appreciation of the realities and challenges facing the South African economy, is necessary to answer this question. The answer should be based on a realistic appreciation of strengths and weaknesses. South Africa and the region have the opportunity to cooperate without the impediment of major political differences. Mutual interdependence should be increased with imports of services such as electricity, water and oil from the region in order to ameliorate the imbalances. South Africa can provide technical support in agriculture, veterinary science, medicine and industry, to mention but a few. Despite South Africa's current political and social transformation, its present economic structure is characterised by an entrenched dualistic nature. The advantages of the country's large and diversified natural resources can be utilised by its modern, formal industrial economy, but foreign participation in its economy is much needed to expand its capacity and simultaneously address the underdeveloped informal sector of the economy.

In this regard, three requirements are essential in a globalised world, not only for South Africa but also for the region as a whole. The most important is the creation of an environment conducive to tourism, business and foreign investment, supported by regional integration and cooperation and an improved outward-orientated economic outlook. Not only would the formal domestic economy then move towards enhancing its unrealised potential, but also the informal economy may benefit from capacity-building owing to increased foreign participation.

\subsection{Investor-friendly environment}

A negative perception of ineffective government can be redressed through flexible institutional arrangements that promote accountability, responsibility and the rule of law. An institution can be defined as a society or organisation established for some object, especially charitable or beneficent (New Oxford Dictionary, 1998). There can be little doubt that southern Africa needs a credible institutional structure which investors and aid agencies are confident is a stable one. This is also one of the best guarantees of a regional spread of investment. Developing countries do not need to create these institutional structures from scratch; they can use existing international agreements and accepted global standards to guide them in establishing credible institutions (World Bank, 1999/2000). The region could, as a starting point, build on its institutional strength provided by the SADC.

A survey by the World Bank (1997: 5) shows that many governments are failing to perform their core functions, which include the protection of property, ensuring law and order and applying rules and regulations in a predictable manner. This affects the 
international credibility of these countries, and their economic growth and investment suffer as a consequence. Although the contents of policies and regulations are important, it is the predictability and consistency with which they are applied that are essential. The creation of a favourable environment is therefore not a luxury pertaining exclusively to industrial countries; it is also a vital element for emerging developing economies. The creation of flexible and meaningful institutions is therefore extremely important to establish an investor-friendly environment conducive to economic growth. This would enhance trust and confidence between nations. This is emphasised by the following statement by Napoleon (cited in World Bank, 1997: 29):

Men are powerless to secure the future; institutions alone fix the destinies of nations.

It is therefore evident that a proper institutional framework should be provided. Moreover, attractive incentives to draw not only foreign, but also domestic investors should be established and be aimed at encouraging effective long-term investment. It is argued by Truu (1997: 55) that 'if nothing else, it is far cheaper to run the economy by means of incentives than controls'. One of the greatest dangers inflicted by a government is the spread of uncertainty. Foreign as well as domestic business and labour should have confidence in the system, in the knowledge that the rules of the game will not be changed overnight. A very important aspect of government is that its ambition should not exceed its capability. This is true especially of weak governments.

\subsection{Self-reliance}

One of the most important guiding principles for developing countries should be to attain greater self-reliance. One dimension of greater self-reliance is increased regional integration and cooperation among countries (Pirages, 1978: 269). Countries have the best prospects for successful integration if they pursue certain objectives. According to standard theory, countries should be at similar levels of economic development with competitive industries so that trade can be created within the region. Also necessary is the potential to develop complementary industries to spread the benefits of integration. Lastly, countries should have a history of substantial trade among themselves (Maasdorp, 1994: 3).

Edoho (1997: 21) states that:

There will be verbal assurances of help from the global community, but the region must not depend on them. Africa should not allow itself to be misguided into thinking of development as a game of catching up with the West. It should not think of the development process as costless and painless. Development involves sacrifices.

Regionalisation and globalisation may be seen as complementary processes occurring in a specific chronological order. World regions, rather than nation states, may in fact constitute the basic units in a future multilateral global order (Hettne, 1997: 225). The problem facing underdeveloped regions that struggle to integrate owing to unequal economic strength between member countries is that they may be left behind altogether in the process of globalisation. This may call for regional flexibility in that different parts of the region should be able to move ahead at a different pace, depending on their readiness for closer economic relations. Caution should be taken, however, that some countries in the region are not winners and others losers. 
The challenge of globalisation for a region should strengthen the desire to cooperate in economic matters to the maximum possible extent. However, the process of integration can only be based on what is realistic and achievable. All countries will not benefit equally from integration, but they should at least be better off inside than outside the group. The framework for the whole process should take the difference of economic development between countries into account and make provision for this. A commitment from all the countries in the region is essential, and policies promoting solidarity and unity aimed at economic prosperity for the region are vital.

Moreover, integration should be mutually beneficial and promote economic development in all the countries without fear of domination by the larger economies. One way of circumventing this is through countertrade. The imbalance of merchandise trade favouring South Africa could be offset at least partly by a greater flow of services such as electricity and water supply from neighbouring countries. Intraregional trade and investment flows should be promoted in anticipation of eventual global awareness and participation in the region. Strengthening the competitiveness of not only individual countries but also the region as a whole will be the intermediate objective, in order to be able to meet the challenges of globalisation.

The process of regionalisation implies a change from relative heterogeneity to increased homogeneity with regard to member countries. The most important aspects here are culture, security, economic policies and political regime (Hettne, 1997: 229). These may collectively be one of the major stumbling blocks in the process of successful globalisation in southern Africa. Regional problems involving neighbouring nations at similar stages in their development are usually easier to solve by cooperation than problems involving nations at different stages of development (Sandier, 1997: 213). The core of the problem is thus endogenously, and not exogenously determined.

\subsection{Outward-orientated approach}

There is little doubt about the link between export performance and economic growth. The question at this point is whether Southern Africa has a comparative advantage in some good or service that has the potential to become truly competitive internationally. Every country, over time, tends to proceed towards comparative advantage in its more specialised goods. Initially exports rely heavily on basic factors such as natural resources and unskilled or semi-skilled labour. Over time, however, more specialised factors such as modern technology and highly skilled labour come to form the backbone of exports. The former type of exports is based on 'natural' comparative advantage and the latter on 'created' comparative advantage (Meier, 1995: 457).

\subsubsection{Tourism}

In the short term, given the constraint of financial capital, labour rigidity and lack of modern technology, southern Africa would have the best chance by focusing on its 'natural' comparative advantage first. The ultimate goal in real globalisation would still be to proceed to its 'created' comparative advantage. In terms of their 'natural' comparative advantage, initially tourism and related sectors would probably play the leading role. Consider the fact that the natural beauty already exists - the 'product' therefore does not need to be produced, only the supporting infrastructure needs to be addressed. This is the link to the creation of the favourable visitor- and investor-friendly environment mentioned earlier. The promotion of communications and 
financial services should take priority, and in this context South Africa has a major role to play in the region. For example, the average number of telephone mainlines in the region is 41,14 per 1000 people, whereas South Africa has 106 telephone mainlines per 1000 people (World Bank, 1998). South Africa also has a highly developed financial and transport infrastructure, not simply in the regional context.

The region has a surplus of labour and these unemployed resources can be channelled into tourism and related sectors, provided the correct training is given and financial resources are allocated correctly. Given the labour multiplier of tourism in South Africa, it is estimated that 33 foreign tourists are necessary to create one job opportunity directly and two indirectly. In 1998, 1,4 million overseas tourists visited South Africa and this can be translated to 43285 job opportunities maintained by tourism during 1998 (Tourism South Africa, 1999). If tourist attractions can be enhanced with a concurrent improvement in the creation of a tourist-friendly environment, the perceived perception of South Africa as a tourist destination may be improved. A report released by the World Tourism Organisation (1998) suggests that southern Africa will experience growth rates in tourism, with forecasts of almost 8 per cent per annum for the decade 2000-10. According to the report, by the year 2002 the region's level of tourism will be five times that of 1990 .

\subsubsection{Export promotion}

In keeping with an outward-orientated approach, the long-term objective would be to address southern Africa's 'created' comparative advantage. As the benefits of 'natural' comparative advantage bear fruit, the inflow of modern technology and skills could contribute to the promotion of more specialised goods. Jeffery Sachs (1998: 23), a prominent American economist says:

There is no way other than through export growth that Africa, or any other region, can achieve growth. For that I will put everything that I know in economics on the line.

This, of course, implies a great deal more than is said here, in a few simple sentences. The dependence on single natural resource-based exports needs to be changed into a focus on manufactured or processed exports. This would lessen the effect of erratic price fluctuations experienced by commodity exports. If the principal exports of southern African countries are evaluated, they certainly reflect the dominance of natural resource-based exports. Countries such as Zimbabwe (tobacco and minerals), Botswana (beef, minerals and some vehicles), Mauritius (textiles, sugar and flowers), Namibia (minerals, fish and live stock) and Malawi (tobacco, sugar and cotton) are examples (SADC, 1998). The real challenge is to develop structures and adopt appropriate policies to establish a productive capacity in manufactured products for export. Macroeconomic stability and appropriate technology policies are also crucial for export growth and diversification. These include trade liberalisation, diversification of exports, infrastructure management and investment in human capital development. The success of trade liberalisation, in turn, depends on necessary reforms in the domestic economy, especially finance and labour. Given the low literacy rate, human capital development is unmistakably one of the top priorities in the region if an outward-orientated approach is to be followed. Productivity improvement is also dependent on the level of training and expertise of the region's human resources. Higher levels of domestic investment in the region are also necessary before it would be able to attract more foreign direct 
investment. According to Mbuende (1998: 14), the saying that charity begins at home is also true of investment.

The challenge is to help nations through organisations such as the SADC to establish linkages with economies at a pace that their governments can manage (Ohmae, 1991: 186). If the pace of liberalising an economy is too rapid, it may tear the social fabric and the result will benefit no one. Truu (1997: 55) argues that the advice to policymakers in this regard would be to 'conquer your fear of freedom!'. This involves a mind-change, because it is difficult to let go of old beliefs. People are familiar and comfortable with them; years went into the development of systems and habits that generally worked well.

Developing countries must remember that they will not be compensated simply because they are poor. They have to earn their rightful place in the global economy by doing the right things, learn from the past and international experience, and adopt internationally credible policies. Countries that do not comply cannot expect any handouts in a globalised world, 'where the official North does not appear to be interested in the welfare of the South' (Cheru, 1997: 220). What hinders economic development is the illusion that effort is irrelevant and that participation in the borderless and global economy is unimportant. It is a question of ambition, will-power and management skill. Fervent nationalism can hide a multitude of sins; it cannot, however, fuel growth or provide a better way of life.

\section{CONCLUSION}

In the modern global economy nothing can be predicted with certainty, since the future is influenced by too many variables. A country may, however, establish an environment that attracts the role-players necessary to boost its domestic economy. The benefits of this process may enable such a country to face the challenges of globalisation.

A country has to earn its trade and investment by creating a friendly environment with complementary incentives and the correct policy mix. What is needed is an investment code of conduct. The international role-players know what they want and they know what they can get from other parts of the world. If a country is serious about attracting foreign resources, economic and business realities cannot make way for social objectives - even if much-needed - since the inflow of foreign resources is necessary to reach those very objectives in the long term. Economic discipline with predictable and consistent macroeconomic policies is required in order to ensure a desirable environment, which is a precondition for attracting global investors. Organised labour needs to take cognisance of the negative impression formed by global role-players of low labour productivity and growing wage demands, which are likely to harm their profitability and thus their willingness to invest. Global investors are not in the game to give handouts. Labour, on the other hand, needs the creation of employment opportunities, as governments need the tax revenues arising from those investments.

Greater regional integration has the advantage of pooling resources and markets, which should give the region greater economic leverage. South Africa, which may be seen as the gateway to southern Africa, can strengthen the image of the region. Its communication systems, transport and financial infrastructure can benefit the region as a whole. Social and political stability in the region - unlike what is happening in Angola and the Democratic Republic of Congo at present - is a necessary precondition for 
economic prosperity and growing welfare. Sustained economic progress is impossible in an unstable political environment.

Most important for the promotion of international competitiveness are the identification and development of the region's comparative advantages and the lobbying for economic policies. Abundant labour resources that may be efficiently used in the tourism and related sectors seem to be the way to promote an outward-orientated approach in the short term. Promotion of diversified manufacturing goods should be the long-term objective. Southern Africa has to accept the fact that raw material resources are no longer the key to economic wealth. Information and human capital - a trained and literate population and not military hardware - are the real sources of economic strength. If foreign companies wish to set up plants or sell products in a country, government should not stand in their way. The involvement of foreign companies is not equal to submission and exploitation, but represents greater economic satisfaction and thus higher levels of wellbeing. The right balance has to be struck between the domestic economy and the global economy. Domestically, economic development and upliftment are part of 'home affairs' and, globally, the stimulation of wealth and income generation is part of 'foreign affairs'.

The question of whether globalisation represents a challenge or a threat to southern Africa depends largely on the following. The ultimate success or failure of the region globally is based on three main principles: the creation of an attractive global destination for international investors and visitors; the acceptance that the keys and instruments to economic success and prosperity lie in its own hands; and the acceptance of the challenges of an outward-orientated approach.

\section{REFERENCES}

ARCHIBUGI, D \& MICHIE, J, 1997. Technological globalisation and national systems of innovation: an introduction. In Archibugi, D \& Michie, J (Eds), Technology, globalisation and economic performance. Cambridge: Cambridge University Press. BETHLEHEM, R, 1991. The global economy: structural change. Prospects for the global economy and their relevance for South Africa. Special occasional paper, 30 September. Johannesburg: South African Institute of International Affairs. BLIGNAUT, JN, 1999. The globalised economy: challenges facing South Africa. Paper presented at the Conference on Moral and Legal Challenges of the Information Era, Pretoria, 24 May.

BUSINESS AFRICA, 1997. 1-15 October. London: Economist Intelligence Unit. CHERU, F, 1997. Global apartheid and the challenge to civil society: Africa in the transformation of world order. In Cox, RW (Ed), The new realism: perspectives on multilateralism and world order. New York: United Nations University Press. EDOHO, FM, 1997. Overview: Africa in the age of globalisation and the new world order. In Edoho, FM (Ed), Globalisation and the new world order: promises, problems and prospects for Africa in the twenty-first century. Westport: Praeger. HETTNE, B, 1997. The double movement: global market versus regionalism. In Cox, RW (Ed), The new realism: perspectives on multilateralism and world order. New York: United Nations University Press.

HOWELLS, J \& WOOD, M, 1993. The globalisation of production and technology. Commision of the European Communities. New York: Belhaven. INTERNATIONAL LABOUR OFFICE (ILO), 1999. South Africa - studies on the social dimensions of globalization. Geneva: ILO. 
MAASDORP, G, 1994. A vision for economic integration and co-operation in southern Africa. Prepared for the Department of Trade and Industry, Pretoria. MARTIN, H \& SCUMANN, H, 1996. The global trap: globalization and the assault on prosperity and democracy. London: Zed.

MBUENDE, K, 1998. SADC as an emerging market. SADC Trade, Industry and Investment Review. Gaborone, Botswana: SADC.

MEIER, GM, 1995. Leading issues in economic development, 6th edn. New York: Oxford University Press.

NEW OXFORD DICTIONARY OF ENGLISH, 1998. Oxford: Harrendon. OHMAE, K, 1991. The borderless world: power and strategy in the interlinked economy. New York: Harper Perennial.

PETRELLA, R, 1996. Globalization and internationalization: the dynamics of the emerging world order. In Boyer, R \& Drache, D (Eds), States against markets: the limits of globalization. London: Routledge, 62-83.

PIRAGES, D, 1978. The new context for international relations: global ecopolitics. Massachusetts: Duxbury.

ROBERTSON, R, 1992. Globalization: social theory and global culture. London: Sage.

SACHS, J, 1998. Radical solutions to Africa's economic woes. Southern African Political and Economic Monthly. Southern African Economist. 2(12): 22-4. SANDLER, T, 1997. Global challenges: an approach to environmental, political and economic problems. Cambridge: Cambridge University Press.

SCOTT, T, 1995. An overview of South Africa's future international economic relations. In Mills, G, Begg, A \& Van Nieuwkerk, A (Eds), South Africa in the global economy. Johannesburg: South African Institute of International Affairs. SOUTHERN AFRICAN DEVELOPMENT COMMUNITY (SADC), 1998. SADC Review. Southern African Marketing Co. Gaborone, Botswana: SADC. THE ECONOMIST, 1994. Does it matter where you are? 30 July, 13-14. TOURISM SOUTH AFRICA

(SATOUR), 1999. Executive Summary. Pretoria: Satour. TRUU, ML, 1997. Wanted: an economic system for South Africa. South African Journal of Economic and Management Sciences, 21(1): 30-60.

VESETH, M, 1998. Selling globalization: the myth of the global economy. London: Lynne Rienner.

WORLD BANK, 1997. World Development Report, 1997: the state in a changing world. New York: Oxford University Press.

WORLD BANK, 1998. African development indicators, 1998. Washington, DC: World Bank.

WORLD BANK, 1998/9. World Development Report, 1998-99: knowledge for development. New York: Oxford University Press.

WORLD BANK, 1999/2000. World Development Report, 1999-2000: entering the 21st century. New York: Oxford University Press.

WORLD TOURISM ORGANISATION, 1998. Hot tourism trends for 21st century. WTO News. July/August. 